\title{
Enhancement of Titanium Alloy Corrosion Resistance via Anodic Oxidation Treatment
}

\section{Hong Jiang}

School of Materials Science and Engineering, University of Shanghai for Science and Technology, No.516,Jungong Road, Yangpu District,Shanghai,200093, P.R. China

E-mail: jianghongvivi@ tom.com

doi: $10.20964 / 2018.04 .47$

Received: 27 November 2017 / Accepted: 18 January 2018 / Published: 6 March 2018

The present work presented the electrochemical treatment of anodic oxidation of TA6V alloy and pure titanium, along with the evaluation of the passivity currents of the TA6V alloy treated under varying conditions. The test electrolyte used in the anodic oxidation was a chromic acid (CA) solution with and without the addition of hydrofluoric acid (HF). On the anodized samples, the passivity current was remarkably decreased, and the range of passive potentials was increased.

Keywords: Anodic oxidation; Titanium alloy; Corrosion resistance; Chronoamperometry; Potentiostatic test

\section{$\underline{\text { FULL TEXT }}$}

(C) 2018 The Authors. Published by ESG (www.electrochemsci.org). This article is an open access article distributed under the terms and conditions of the Creative Commons Attribution license (http://creativecommons.org/licenses/by/4.0/). 